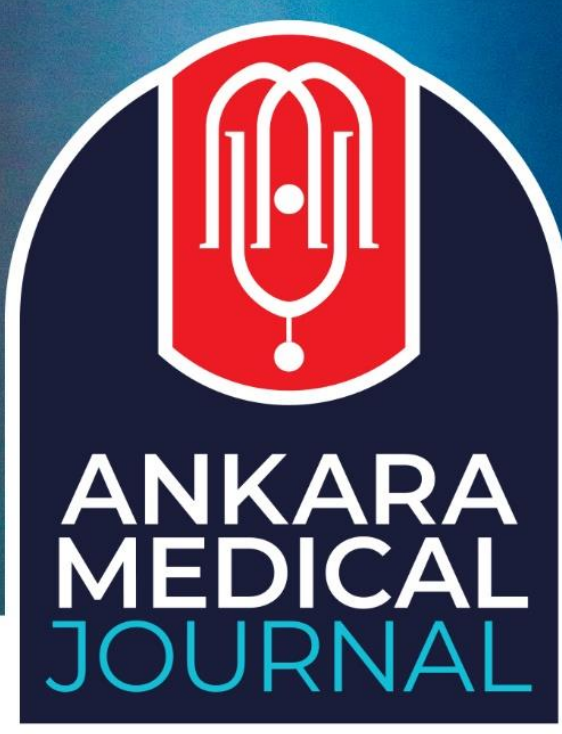

Research Article

Ankara Med J, 2020;(4):1053-1060 // 10.5505/amj.2020.04468

\title{
INCIDENCE OF BRAIN DEATH AMONG PATIENTS WITH BRAIN INJURY IN INTENSIVE CARE UNIT: A RETROSPECTIVE STUDY
}

\section{YOĞUN BAKIM ÜNİTESINNDE BEYINN HASARI OLAN HASTALAR ARASINDA BEYİN ÖLÜMÜ İNSIDDANSI: RETROSPEKTİF ÇALIŞMA}

(D) Mustafa Sırrı Kotanoğlu1, (D) Çiğdem Kızılay1

${ }^{1}$ Training and Research Hospital, Department of Anesthesiology and Reanimation, Ankara

Yazışma Adresi / Correspondence:

Dr. Öğr. Üyesi Mustafa Sırrı Kotanoğlu (e-mail: mskotan@gmail.com)

Geliş Tarihi (Submitted): 22.10.2020 // Kabul Tarihi (Accepted): 19.11.2020

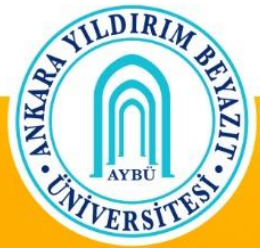

Ankara Yıldirım Beyazit University Faculty of Medicine Department of Family Medicine 


\title{
Öz
}

Amaç: Beyin ölümü kavramı klinik olarak uyarılara tam cevapsızlık hali, solunum ve motor cevabın olmaması, beyin sapı reflekslerinin yokluğu ve koma tablosunun mevcudiyeti ile tüm beyin fonksiyonlarının tam ve geri dönüşümsüz olarak kaybı ile karakterize bir klinik tablo olarak tanımlanmaktadır. Türkiye'de sınırlı donör kaynakları ve yüksek aile reddi nedeniyle beyin ölümü ve potansiyel bağışçıların belirlenmesi büyük önem arz etmektedir. Burada üçüncü basamak erişkin yoğun bakım ünitesinde beyin ölümü gelişen hastaları ve kadavra donörlerini geriye dönük olarak değerlendirmeyi hedefliyoruz.

Materyal ve Metot: 2008-2019 yılları arasında beyin ölümü tanısı alan hastaların tıbbi kayıtları geriye dönük olarak değerlendirildi. Hastaların demografik özelliklerini, klinik tanılarını ve bağış oranlarını kaydedildi.

Bulgular: 2008-2019 yılları arasında yoğun bakım ünitesinde toplam 102 beyin ölümü hastası teşhis edildi. Hastaların ortalama yaşı 49 (16-84, min-maks), \%55,88'i erkek ve \%44,11'i kadındı. Klinik tanılar spontan intrakraniyal kanama (\%50), travmatik intrakraniyal kanama $(\% 28,43)$, kardiyak arrest $(\% 12,74)$ ve serebral infarkt $(\% 7,84)$ idi.19 $(\% 18,62)$ hastada organ bağıșı onaylanırken 83 hastada reddedildi. Yoğun bakıma başvuru ile apne testi arasında geçen süre ortalama 3,56 gün olarak belirlendi.

Sonuç: Bu çalışmada, beyin ölümü tanı oranlarının arttığını, ancak kadavra donörden organ bağışı oranlarında değişiklik olmadığını tespit ettik. Sağlık çalışanları, organ bağışı oranlarını artırmak için organ bağışı ve organ bağışı gönüllülüğü konusundaki farkındalığı arttırmaya odaklanmalıdır.

Anahtar Kelimeler: Beyin ölümü, organ bağıșı, yoğun bakım.

\begin{abstract}
Objectives: The concept of brain death is clinically defined as the absence of spontaneous respiration, brain stem reflexes, and motor responses, presence of coma, and irreversible cessation of brain function, including the cerebral and brain stem functions completely. Because of limited donor sources and high family refusal in Turkey, to determine brain death and potential donors is very important. Here we aim to evaluate the braindead patients and cadaver donors in a tertiary level adult intensive care unit, retrospectively.

Materials and Methods: We evaluated the medical records of brain-dead patients diagnosed between the years 2008-2019, retrospectively. We recorded the demographics of the patients, clinical diagnosis, and donation rates.

Results: A total of 102 brain dead patients were diagnosed in the intensive care unit between the years 20082019. The median age of the patients was 49.16 (16-84, min-max), $55.88 \%$ was male and $44.11 \%$ was female. The clinical diagnoses were spontaneous intracranial hemorrhage (50\%), traumatic intracranial hemorrhage (28.43\%), cardiac arrest (12.74\%), and cerebral infarct (7.84\%). Organ donation was approved in 19 (18.62\%) patients and refused in 83 patients. The time between admission to the intensive care unit and apnea test was determined as a mean of 3.56 days.

Conclusion: In the present study, we recognized the increased rates of brain death diagnosis, but there was no change in donation rates of cadaver donors. Health professionals should focus on promoting awareness of organ donation and volunteering to donate in order to increase donation rates.

Keywords: Brain death, organ donation, intensive care.
\end{abstract}




\section{Introduction}

Brain death is defined as the irreversible cessation of brain function, including the cerebral and brain stem functions completely. Brain death can be determined according to clinical criteria in patients who still have a cardiac function during mechanical ventilation. ${ }^{1,2}$ Today, organ transplantation is a common therapeutic strategy for patients with end-stage organ disease, and organs for donation are procured from both brains, dead organ donors, and living donors. ${ }^{3}$ There is an increasing discrepancy between the number of patients on the waiting lists for organ transplantation and the available number of deceased donor organs. Data from the United Network for Organ Sharing indicated that in 2004, there were 95,000 patients listed for solid organs in the United States, but only 27,000 transplants were performed that year. ${ }^{4}$

In different countries, different legislations are in place to regulate organ donation from brain-dead organ donors. Entered into force in our country in 1979, law numbered 2238 on organ and tissue receipt, storage and transport, and the diagnosis of brain death placing determined. ${ }^{3}$ Finally, with the change made by the Ministry of Health in 2014, two physicians (neurology or neurosurgery specialist and anesthesiology and reanimation specialist or intensive care specialist) unanimously in accordance with evidence-based medicine rules, a decision is made. ${ }^{4}$ The widespread support of the existing law for organ donation in Turkey is encouraging. But the supply of donor organs for transplantation still fails to meet the demand. Due to the shortage of suitable organs from brain dead patients, the number of patients on the waiting lists exceeds the number of brain-dead organ donors and patients die whilst waiting for transplantation. ${ }^{5}$

As the number of deceased organ donors is still not sufficient to meet the demand for transplantable organs, almost all organ donations (75\%) come from living donors in Turkey.

According to the literature, the ratio of donation consent given by families of the potential donors ranges between $0 \%$ to $75 \%$ and also differs largely between different geographic areas and ethnic groups. ${ }^{6,7}$ Therefore, the diagnosis of brain death and evaluation of the potential donor is crucial. The aim of this study was to evaluate the brain-dead patients and deceased donors at a Level III adult intensive care unit, retrospectively.

\section{Materials and Methods}

This single-center retrospective study was conducted after local ethics committee approval ( $15^{\text {th }}$ October 2020; 93471371-514.10) in a Level III adult intensive care unit between 2008 and 2019. The same method was used in all patients for clinical evaluation and diagnosis of brain death. Glasgow Coma Scale (GCS) score was determined at admission to the intensive care unit and during the stay, and all patients with GCS score 3 were assessed in terms of brain death. In patients with catastrophic brain damage, the GCS score 3 and the absence 
of brainstem reflexes, the apnea test was performed in accordance with the legal regulations made by the Ministry of Health. ${ }^{8}$

To evaluate and identify the number of brain-dead patients, demographics of the patients, other clinical diagnoses, and donation performance, medical charts of the patients who were diagnosed as brain death in the intensive care unit between 2008 and 2019 were retrospectively reviewed. After the diagnosis of brain death in the intensive care unit, all the data of the patients were registered in a web-based system (Turkish Organ and Tissue Data System) by the transplant coordinator of the hospital.

The descriptive statistics, including frequencies, percentages, and mean $( \pm \mathrm{SD})$, were estimated appropriately.

\section{Results}

The total number of potential organ donors who were diagnosed with brain death in the intensive care unit from 2008 to 2019 was 102.

The median age of the patients was 49.16 (16-84, min-max), 55 (55.88\%) was male and 45 (44.11\%) were female. The mean age of male and female patients were $47.12 \pm 18.6$ and $51.73 \pm 19,7$ years, respectively. The clinical diagnoses were spontaneous intracranial hemorrhage (50\%), traumatic intracranial hemorrhage (28.43\%), cardiac arrest (12.74\%), and cerebral infarct (7.84\%).

There were 15 male and 4 female deceased donors. Apnea test was performed in 75 (73.52\%) patients. The time between the admission to the intensive care unit and apnea test was determined as a mean of $3.56 \pm 3.1$ days.

The annual consent rate of families for organ donation increased from $0 \%$ to $15.7 \%$ in 2008 to 2019 , respectively. Considering the total number of potential donors, 18.62\% (19 patients) registered consent and $81.37 \%$ (83 patients) registered to refuse after the suggestion of organ donation by the transplant coordinator of the hospital.

\section{Discussion}

This study showed that the rates of brain death diagnosis increased, but there was no significant change in donation rates of cadaver donors. The number of brain-death diagnosis was between 5 to 24 annually between the years 2008-2019. Despite this, the cadaver organ donor number was between 1 to 3 . 
When organ donation is assessed considering cadaver donors to one million population, the ideal ratio is found to be 50 cadaver donors/million. The ratio is 20-30 cadaver donors/million around Europe. ${ }^{9}$ In the literature this ratio is reported to be 33.6-34.6 in Spain, 25.2 in Belgium, 21.1 in Italy, 20 in the USA, 16.2-20.9 in France, 14.1 in Canada, 13.8 in Germany, and 4.5-6.2 in Greece. ${ }^{10}$ In Turkey, deceased donation rates per million population was 5.1 and is markedly lower than European Countries. ${ }^{11-12}$ Although, according to Turkish Tissue Organ and Transplant Service data, the number of brain death diagnosis was increased from 1313 to 2042 from the year 2011 to $2017,25 \%$ of the cases diagnosed with brain death had organ donations between these years. Moreover, as of 2017, around 25,000 patients are on the organ donation waiting list. In general, although the number of cases diagnosed with brain death has increased over the years, deceased donation rates are quite low.13

In the literature, whereas the rate of deceased donation in the United States and European countries are 54\% and more than $80 \%$, respectively, the rate of deceased donation in Turkey is $25 \%{ }^{6,7,13-15}$ In this study, when all brain death cases are taken into consideration, the registered consent rate is $18.6 \%$. The main reason for potential donor losses is the high family refusal rate. It is reported that the family refusal rates were $46 \%$ in the United States, $41 \%$ in the United Kingdom, and 10.5\% in France and Belgium. ${ }^{14,16-18}$ However, $73.3 \%$ of registered refuse in the Turkish National Coordination Centre. ${ }^{6,7}$ The Spanish system differs significantly about deceased donation. Organ donation and family rejection rates in Spain were reported to be around 50-60\% and $10-15 \%$, respectively. On the other hand, it has been determined that the main obstacle in organ donation stems from medical contraindications. ${ }^{19}$ In the Turkish population, whereas the rate of volunteering for organ donation was $57 \%$, the rate of consent for organ donation by relatives was $52.6 \%$. The change in public attitude in Turkey changed 12 years after establishing a successful transplant program. ${ }^{20}$ Yllmaz et al. demonstrated that the rate of volunteering for organ donation increased from $45.4 \%$ to $84.8 \%$ and the rate of consent for organ donations by relatives increased from $41 \%$ to $80.3 \%$ after education. ${ }^{21}$ The percent of having general knowledge about organ donation is $34.8 \%$ and most participants have a lack of information or incorrect information and wrong beliefs about organ donation. Although the population in Turkey has inadequate information about organ donation and transplantation, live donor percentages are higher than in Europe. ${ }^{7}$ It was believed that the most important factor affecting the decision of approving organ donation by the families of brain dead patients was the attitude, reliability, and persuasiveness of intensive care unit doctors. Therefore the relation between the intensivists and the families of patients has a crucial role to increase organ donation. ${ }^{22,23}$

In a Turkish study, only $23 \%$ of the physicians and $11 \%$ of the nurses were willing to donate an organ. The percentage of healthcare providers willing to become an organ donor correlates with the workers' knowledge and attitude toward the transplantation process. For this reason, The Organ, Tissue, and Transplantation 
Services of The Turkish Transplant Foundation started a project to improve the decision-making process. This process was developed for all professionals who approach families to request organ and/or tissue donation.

The majority of organs transplanted originate from brain dead organ donors. A multitude of strategies has been implemented to increase organ donor rates. It has been shown that social and cultural issues, attitudes of the general public and health care professionals, and religious beliefs, personal experience with organ donation have played important roles in organ donation. ${ }^{7}$. A study was done in the European Union showed that presumed consentorgan donation policy positively affects the willingness of individuals to donate their own organs and those of relatives. ${ }^{24}$ According to similar studies in the literature, individuals do not have sufficient knowledge and sensitivity about organ donation. However, there is a strong correlation between education level and voluntary organ donation. 55\% to $95 \%$ of the individuals in society indicated that the most important information source was print and visual media and they were affected by the negative news. Therefore, the function of print and visual media should be well utilized to inform society about organ donation. ${ }^{25}$

In multi-center studies, the diagnosis of brain death has been reported in cases with catastrophic brain damage such as cerebral hemorrhage and trauma. ${ }^{26,27}$ On the other hand, Kompanje et al., stated that the most common cause of brain death was subarachnoid hemorrhage. ${ }^{28}$ In our study, spontaneous intracranial hemorrhage is the most common cause of brain death. Other causes of brain death were traumatic intracranial hemorrhage, cardiac arrest, and cerebral infarct.

In two studies conducted in different centers in our country, the average diagnosis time for brain death was determined to be between three days and one week, and organ donation rates were found to be $29.3 \%$ and $34.2 \% \cdot{ }^{29,30}$ In the present study, the average time between the admission of patients to the intensive care unit and the apnea test was determined to be 3.56 days.

As a result, the main reason for the potential donor losses is the high family refusal rates due to a lack of knowledge about brain death and organ donation. It could be explained by the inappropriate sources of information and incorrect beliefs about transplant and donation. Moreover, a wider range of the general population should be informed about the legislation and religious approach to organ donation. Therefore, educational programs for professionals and public information could be a possibility to increase brain dead awareness and organ donation. In addition, to increase the diagnosis of brain death, targeted education and training programs for health care professionals are warranted. Health professionals should focus on to promote awareness of organ donation and volunteering to donate in order to increase donation rates. We hope that the awareness regarding organ donation may certainly be improved and impact the motivation of the people towards organ donation. 


\section{References}

1. A definition of irreversible coma. Report of the Ad Hoc Committee of the Harvard Medical School to Examine the Definition of Brain Death. JAMA 1968; 205 (6): 337-40. (doi:10.1001/jama.1968.03140320031009).

2. Farrell MM, Levin DL. Brain death in the pediatric patient: historical, sociological, medical, religious, cultural, legal and ethical considerations. Crit Care Med 1993; 21(12): 1951-65. (doi: 10.1097/00003246-199312000-00025).

3. Filho MA, Ramalho H, Pires HS, Silveira JA. Attitudes and awareness regarding organ donation in the western region of Sao Paulo. Transplant Proc 1995;27(2):1835.

4. UNOS. Waiting list data: United Network for Organ Sharing 2001. UNOS Data and Transplantation Statistics. Organ Donation Data [Internet]. https://unos.org/data (Accessed 20.10.2020).

5. Emiral GO, Atalay BI, Altunok H, Gokler ME, Onsuz MF et al. Development of a reliable and valid organ tissue donation and transplantation knowledge scale. Transplantation Proceedings 2017; 49: 260 -6. (doi:10.1016/ j.transproceed.2016.11.036).

6. Bilgel H, Sadikoglu G, Goktas O, Bilgel N. A survey of the public attitudes towards organ donation in a Turkish community and of the changes that have taken place in the last 12 years. Transplant International 2004; 17 (3):126-30. (doi.org/10.1111/j.1432-2277.2004.tb00416.x).

7. Yucetin L, Kececioğlu N, Ersoy FF. Türkiye'de organ bağıșı ve nakline bir bakıș. Dialysis, Transplantation and Burns 2003; 14 (2): 115-8.

8. Turkish Neurological Society - Diagnostic Guidelines for Brain Death. Turk J Neurol 2014;20(3):1014.

9. Manyalich M, Costa AN, Paez G. IRODaT 2008 International donation and transplantation activity. Organs, Tissues and Cells 2009;12:85-88.

10. European Commission. Organ donation and transplantation: facts and figures; 9 Oct 2012; Journalists' Workshop [Internet]. https://ec.europa.eu/health//sites/health/files/blood_tissues_organs/docs/ev_20121009_facts_figu res.pdf (Accessed: 20.10.2020).

11. European Commission Journalist Workshop on Organ Donation and Transplantation Recent Facts and Figures. 26 November 2014 [Internet]. https://ec.europa.eu/health/sites/health/files/blood_tissues_organs/docs/ev_20141126_factsfigure S_en.pdf (Accessed: 20.10.2020).

12. Rudge C, Matesanz R, Delmonico FL, Chapman J. International practices of organ donation. Br J Anaesth 2012;108 (Suppl 1): i48-i55. (doi.org/10.1093/bja/aer399). 
13. Turkish Ministry of Health, Department of Organ, Tissue Transplantation and Dialysis [Internet]. https://organ.saglik.gov.tr/TR_HIZMET/hizmetler_bagis.aspx (Accessed: 20.10.2020).

14. Sheehy E, Conrad SL, Brigham LE, Luskin R, Weber P et al. Estimating the number of potential organ donors in the United States. N Engl J Med 2003; 349 (7): 667-74. (doi: 10.1056/NEJMsa021271).

15. Jansen NE, van Leiden HA, Haase-Kromwijk BJ, Hoitsma AJ. Organ donation performance in the Netherlands 2005-08; medical record review in 64 hospitals. Nephrol Dial Transplant 2010; 25 (6): 1992-7. (doi: 10.1093/ndt/gfp705).

16. Barber K, Falvey S, Hamilton C, Collett D, Rudge C. Potential for organ donation in the United Kingdom: audit of intensive care records. BMJ 2006; 332 (7550): 1124-7. (doi: 10.1136/bmj.38804.658183.55).

17. Wesslau C, Grosse K, Krüger R, Kücük O, Mauer D et al. How large is the organ donor potential in Germany? Results of an analysis of data collected on deceased with primary and secondary brain damage in intensive care unit from 2002 to 2005. Transpl Int 2007; 20 (2): 147-55. (doi: 10.1111/j.1432-2277.2006.00413.x).

18. Roels L, Spaight C, Smits J, Cohen B. Donation patterns in four European countries: data from the donor action database. Transplantation 2008; 86 (12): 1738-43. (doi: 10.1097/TP.0b013e3181908e08).

19. Matesanz R, Domínguez-Gil B, Coll E, de la Rosa G, Marazuela R. Spanish experience as a leading country: what kind of measures were taken? Transpl Int 2011; 24 (4): 333-43. (doi: 10.1111/j.14322277.2010.01204.x).

20. Bilgin N, Akgun HS. A focus on health care professionals in organ donation: a crosssectional survey. Transplant Proc 2002; 34 (6): 2445-7. (doi: 10.1016/s0041-1345(02)03172-x).

21. Yllmaz TU. Importance of education in organ donation. Exp Clin Transplant 2011; 9 (6): 370-5.

22. Topbas M, Turkyilmaz S, Can G, Ulusoy S, Kalyoncu M et al. Information, attitude, and behavior toward organ transplantation and donation among health workers in the eastern Black Sea region of Turkey. Transplant Proc 2011; 43 (3): 773-77. (doi: 10.1016/j.transproceed.2011.02.073).

23. Williams MA, Lipsett PA, Rushton CH, Grochowski EC, Berkowitz ID et al. The physician's role in discussing organ donation with families. Crit Care Med 2003; 31 (5): 1568-73. (doi: 10.1097/01.CCM.0000063090.21056.A6).

24. Mossialos E, Costa-Font J, Rudisill C. Does organ donation legislation affect individuals' willingness to donate their own or their relative's organs? Evidence from European Union survey data. BMC Health Serv Res 2008, 8: 48. (doi: 10.1186/1472-6963-8-48).

25. Morgan SE, Harrison TR, Long SD, Afifi WA, Stephenson MT et al. Family discussions about organ donation: how the media influences opinions about donation decisions. Clin Transplant 2005; 19 (5): 674-82. (doi: 10.1111/j.1399-0012.2005.00407.x). 
26. Bodi MA, Pont T, Sandiumenge A, Oliver E, Gener J et al. Brain death organ donation potential and life support therapy limitation in neurocritical patients. Med Intensiva 2015; 39 (6): 337-44. (doi: 10.1016/j.medin.2014.07.010).

27. Escudero D, Valentin MO, Escalante JL, Sanmartin A, Perez-Basterrechea M et al. Intensive care practices in brain death diagnosis and organ donation. Anaesthesia 2015; 70 (10): 1130-9. (doi: 10.1111/anae.13065).

28. Kompanje EJ, de Groot YJ, Bakker J. Is organ donation from brain dead donors reaching an inescapable and desirable nadir? Transplantation 2011; 91 (11): 1177- 80. (doi: 10.1097/TP.0b013e3182180567).

29. Altınsoy S, Özdemir EŞ, Baran İ, Akelma FK, Arslan MT et al. Beyin ölümü tanısı alan hastaların değerlendirilmesi ve yeni yönetmeliğin tanı süresine etkisinin araştırılması. Turk J Intensive Care 2020; 18: 21-7 (doi: 10.4274/tybd.galenos.2019.09825).

30. Battal M, Horoz A, Karatepe O, Çitgez B. Beyin ölümü tespitinde araştırma hastanesi deneyimi. SETB 2013; 47 (2): 59-62. (doi: 10.5350/SEMB2013470203). 